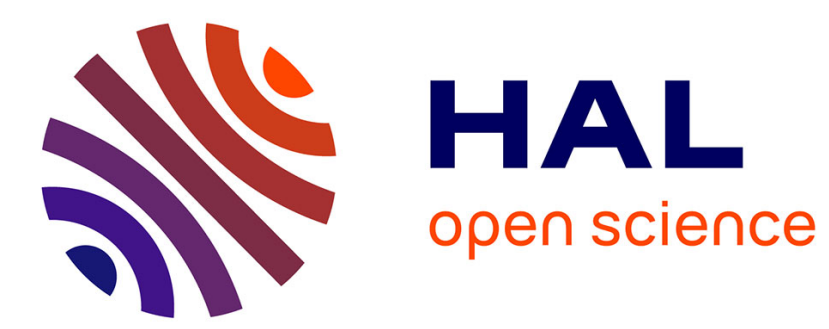

\title{
A Dark Side of Social Capital? Kinship, Consumption, and Savings
}

Salvatore Di Falco, Erwin Bulte

\section{To cite this version:}

Salvatore Di Falco, Erwin Bulte. A Dark Side of Social Capital? Kinship, Consumption, and Savings. The Journal of Development Studies, 2011, pp.1. 10.1080/00220388.2010.514328 hal-00722232

\section{HAL Id: hal-00722232 \\ https://hal.science/hal-00722232}

Submitted on 1 Aug 2012

HAL is a multi-disciplinary open access archive for the deposit and dissemination of scientific research documents, whether they are published or not. The documents may come from teaching and research institutions in France or abroad, or from public or private research centers.
L'archive ouverte pluridisciplinaire HAL, est destinée au dépôt et à la diffusion de documents scientifiques de niveau recherche, publiés ou non, émanant des établissements d'enseignement et de recherche français ou étrangers, des laboratoires publics ou privés. 


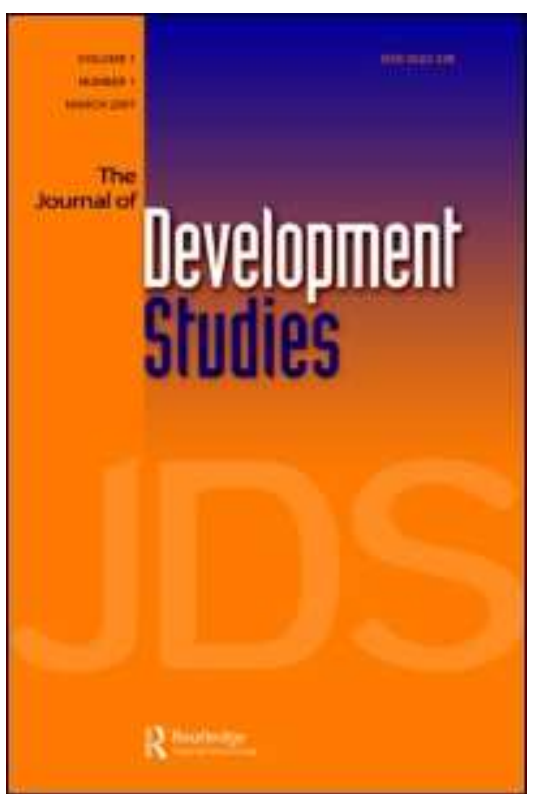

A Dark Side of Social Capital? Kinship, Consumption, and Savings

\begin{tabular}{|r|l|}
\hline Journal: & Journal of Development Studies \\
\hline Manuscript ID: & FJDS-2009-Aug-0035.R2 \\
\hline Manuscript Type: & Original Manuscripts \\
\hline Keywords: & Traditional sharing norms, Kinship \\
\hline \multicolumn{2}{|l}{} \\
\hline
\end{tabular}

\section{今 scholaronE" \\ Manuscript Central}




\title{
A Dark Side of Social Capital?
}

\author{
Kinship, Consumption, and Savings
}

\begin{abstract}
We explore if traditional sharing norms in kinship networks affect consumption and accumulation decisions of poor black households in Kwazulu-Natal, South Africa. Using a proxy for the number of family dependents, our results are consistent with the interpretation that households try to evade their 'sharing obligations' by (i) accumulating durables that are nonsharable at the expense of durables that may be shared and (ii) reducing savings in liquid assets. By attenuating accumulation incentives, kinship sharing may come at the expense of income growth - if so, a culturally-induced poverty trap can possibly eventuate. We demonstrate tentative evidence that more extensive kinship networks are associated with lower incomes.
\end{abstract}

Keywords: Traditional sharing norms, spending, accumulation of wealth, sub-Saharan Africa.

JEL Codes: D12, O16, 017 


\section{Introduction}

In the absence of 'formal' financial markets and insurance opportunities, many people in developing countries depend on informal community structures to provide social security and reduce their exposure to risk (e.g., Rosenzweig, 1988; Fafchamps, 1991; Townsend, 1994; Udry, 1994; Fafchamps and Lund, 2003). A key role in this respect is played by the extended family (kinship), where membership of a kinship network is acquired by bloodlines, marriage, or adoption. Kinship is a collective institution, and represents a primary principle of social organization in sub-Saharan Africa (and some Asian countries, like the Philippines and Vietnam), governing social relationships and marital customs, and regulating access to resources and services.

Unlike friendship networks, which are typically voluntary and based on reciprocity (such that incentive constraints imply limited mutual insurance possibilities, as modeled by Coate and Ravallion, 1993), kinship relations may define obligations for its members. In this respect, Scott (1976) and Platteau (1991) refer to the 'moral economy' of societies characterised by kinship relations, and Hoff and Sen (2006) talk about a 'social contract' among members of an extended family (see also Fortes 1969). Moral obligations towards sharing and redistribution are supported by custom and norms, enabling kinship members to claim assistance from their relatives in dealing with difficulties. Fortes (1969) refers to this as 'sharing without reckoning,' and Gulliver (1971) remarks that the statement 'you must help a man because he is your kinsman' has the same constraining quality as the statement 'you must cultivate because you need food to live.' In light of this it is no surprise that Coate and Ravallion (1993) remark that, among anthropologists, a rather 'romanticised view' of kinship-based sharing systems has long been dominant. Kinship is celebrated as a successful indigenous institution. In the African context it represents a major component of social capital, and provides a safety net for the unlucky. 
One might wonder whether this risk-pooling service comes at a price. The prospect of forced redistribution may impact on spending and savings decisions. Lewis (1955) recognises such adverse incentive effects when writing about successful kinship members who "may be besieged by ... increased demand for support from a large number of distant relatives.' Similarly, Bauer and Yamey (1957) mention sharing obligations may '... obstruct the spreading of the banking habit since people are unwilling to have bank accounts the content of which are likely to be divulged to kinsmen. Generally, it weights the scales against [conspicuous] investment.' Compulsory contributions to the family pool—akin to a 'family tax'—-therefore may discourage individuals to work hard and accumulate assets.

What evidence exists for the perspective that the moral economy implies 'sharing without reckoning,' or the alternative conjecture that it is inimical to economic growth? Anecdotal evidence that kinship obligations affect behavior is provided in, for example, Kennedy (1988), Platteau (2000). However, there are few empirical analyses linking kinship membership to consumption and investment. One study focusing on kinship and behavior is Baland et al. (2009), who analyze borrowing behavior in Cameroon, finding that some people 'pretend to be poor' by both depositing and borrowing money. While excess borrowing is costly, it signals poverty and suggests an inability to respond to demands for financial assistance from kin members. Di Falco and Bulte (2009) demonstrate that the propensity to invest in soil and water conservation in the Ethiopian Nile Basin is reduced as the size of the local kinship network is greater-a result that is consistent with moral hazard as well as 'avoiding the family tax.'

The main objective of this paper is to explore the empirical relationship between traditional sharing rules in kinship networks and household consumption and savings decisions. We use detailed survey data from KwaZulu-Natal (Republic of South Africa) to link household expenditures to a proxy of the size of a household's kinship network. Specifically, we analyze whether consumption and savings are correlated with a subset of the extended family. We 
address 'endogeneity concerns' through panel estimations and IV models. Our results are consistent with the hypothesis that traditional sharing rules invite evasive behavior. If so, traditional sharing rules could possibly contribute to the existence of poverty traps by discouraging investments and savings.

This paper serves as a reminder of the importance of cultural factors and social norms as potential drivers or impediments to development - an idea that has become rather snowed under in recent decades when attention was focused on the roles of markets and (formal) institutions. It also contributes to the literature relating economic development to social capital, where social capital may be defined as norms that enhance the incentive compatibility of non-contractual or legally enforceable exchange (e.g., Carter and Castillo, 2002). Kinship may help to restrain opportunistic behavior of members for the common good, lower transaction costs, facilitate the exchange of information, and enable communities to overcome social dilemma situations. Most of the evidence available for Kwazulu-Natal supports the idea that social capital proxies such as group membership, trust, trustworthiness and altruism positively impact on household well-being (Maluccio et al., 2000; Haddad and Maluccio, 2003; Carter and Castillo, 2009). ${ }^{6}$ However, our focus on traditional sharing norms is qualitatively different, and the implied distortive incentive effects could represent a 'dark side' of social capital. This complements another 'dark side perspective' identified in the context of endogenous formation of networks (i.e. where individuals self-select into networks). Chantarat and Barrett (2008) demonstrate that involuntary exclusion from such networks can condemn the poor to perpetual poverty. Hence, depending on the nature of the network and the nature of the demands that eventuate within it, both too few as well as too many links to others in the network can undermine income growth prospects of the poor.

The paper is organised as follows. In section 2 we provide some context and briefly discuss poverty dynamics and sharing norms in Kwazulu Natal. Section 3 outlines our empirical 


\section{Poverty in Kwazulu Natal}

Kwazulu-Natal is the most populous province of South Africa, home to approximately 20 percent of the South African population. The great majority of the population are black Africans $(82 \%)$. Kwazulu-Natal faces many challenges in the development sphere, including widespread poverty and unemployment, marked inequality, as well as high rates of violence and HIV-AIDS prevalence. Perhaps for these reasons, it was selected as a region for starting a longitudinal research project on poverty dynamics. In 1993, the Project for Statistics on Living Standards and Development (PSLSD) had collected data on a wide range of household variables throughout South Africa. In 1998 and 2004, the Kwazulu-Natal Income Dynamics Study (KIDS) resurveyed the Kwazulu-Natal PSLSD households, constructing a panel set of three waves for that province. ${ }^{7}$ While the PSLSD provides a representative household database, the KIDS waves resurveyed only blacks and Indians. The same questions as in the PSLSD survey were included in the KIDS surveys, but the latter also included new components, including more emphasis on non-residents economically linked to the household, information on trust, shocks, etc. For details about study background, attrition rates and so on, please refer to May et al. (2006). 
The available data demonstrate an overall increase in poverty and inequality since 1993 (e.g. Adato et al., 2007), but also a reversal of this trend in the post-1998 period (May et al., 2006). Focusing on the sub-sample of households for which we have three rounds of data, we observe that the poverty headcount increased from $52 \%$ in 1993 to $57 \%$ in 1998 , and then fell to $47 \%$ in 2004. Poverty dynamics are characterised by significant chronic poverty (most of the poor stay poor), but also upward and downward mobility. In fact, May et al. (2006) mention bifurcation among those households hovering near the poverty line-some $40 \%$ moved up and an equally large group fell below the poverty line. Households at the top of the income distribution either maintained or increased their income, hence the overall picture is one of increasing inequality.

Focusing on the bottom of the distribution, several studies have examined how the poor and unemployed cope in the absence of formal support. Various coping strategies have been identified, including village-level social capital (Carter and Maluccio, 2003), spatially-extended migrant networks within which social grants are leveraged (Du Toit and Neves, 2009), and endogenous household formation ${ }^{8}$ (Klasen and Woolard, 2008).

\section{Empirical Strategy and Data}

We have in mind a world in which income depends on labour time and a random shock. Once it realises its income, the household can take some part of its income outside of the pool of resources on which the extended family can draw. There is no asymmetric information, and kin members are aware of each-other's asset portfolio. While this is undoubtedly a simplification, it is unlikely that information about income and assets can be kept secret from family members (who have an interest in finding out about these matters). The purpose of the empirical work is to investigate the evidence that households with greater kin obligations make different spending decisions than those with fewer kin obligations, and that the nature of those differences is consistent with the hypothesis of evasion from kin group obligations. Specifically, since kin 
obligations are similar to a tax, we postulate that kin obligations reduce demand for normal or luxury goods subject to the family tax.

We estimate a set of budget share equations, and distinguish between sharable and nonsharable goods (where sharable refers to appropriable by kinship members at the expense of the household—sharable implies potentially 'taxable' $).{ }^{9}$ We expect that consumption expenditures vary systematically with the kinship network. Consumption of non-sharable goods is expected to increase as the kinship network is larger, and consumption of sharable goods is expected to go down as the extended family is larger. We also consider the share of savings.

Let $x_{h}$ denote a measure of amount of resources in the household (i.e. total consumer expenditure) and let $w_{i h}$ be the corresponding budget share for categories $i=1, \ldots, 4$ and for households $h=1, \ldots, \mathrm{H}$. We can write an Engel curve as follows:

$$
w_{i h}=\alpha_{0}+\alpha_{1} \ln x_{h}+\alpha_{3} k_{h}+\alpha_{4} A_{h}+v_{i h},
$$

where $k_{h}$ is the value of our kinship variable for the $h^{\text {th }}$ household, $A_{h}$ is a vector of controls, and $v_{i h}$ is the error term. ${ }^{10}$ In budget share models, $x_{h}$ is usually considered potentially endogenous hence $\mathrm{E}\left(x_{h} \mid v_{i h}\right) \neq 0$. Conventionally, in empirical analyses of Engel curves, the household's level of income as well as income squared are used as instrumental variables, $z_{h}$. This implies assuming $\mathrm{E}\left(z_{h} \mid v_{i h}\right)=0$ (e.g., Blundell et al., 1993). We also consider the kinship variable to be endogenous (see below).

We have access to three waves of data, and for our identification strategy we exploit both the cross section and panel nature of the dataset. This allows us to deal with endogeneity and time-invariant household heterogeneity. Both dimensions have their own advantages and disadvantages, but as complementary perspectives they are able to tell a convincing story. The most straightforward way to deal with endogeneity is to use a fixed effects panel approach, focusing on within-subject variation over time. The fixed effect estimator however can suffer when there is limited variation in the extended family proxy over time. Lack of sufficient 
variation in an explanatory variable over time implies that the panel estimation procedure may exaggerate measurement bias_biasing the kinship coefficient to zero (McCallum, 1972). Besides lack of sufficient variation, there may still be correlation between the error term and the endogenous variables that is related to time variant factors.

To address the possibility of endogeneity bias attributable both to omitted time invariant heterogeneity and measurement error we estimate model (1) via three different estimators: (i) panel with fixed effects, (ii) instrumental variables (IV) on pooled data, and (iii) IV with fixed effects.

Some of our control variables do not (or hardly) vary over the time span of the three survey waves (e.g., proximity to infrastructure, or whether the household is rural or not). Some fixed effects procedures remove household specifics via first differencing or implementing deviations from variable means. These transformations remove unobserved time-invariant heterogeneity as well as variables that do not vary through time. To circumvent this problem we adopt the Mundlak specification of household effects (Mundlak, 1978; Wooldridge, 2002) to control for time-invariant unobservables at the household level, and estimate a pseudo-fixed effects model. The right hand-side of our regression equations includes the mean value of the time-varying explanatory variables. This approach relies on the assumption that unobserved effects $\left(v_{i h}\right)$ are linearly correlated with explanatory variables as specified by:

$$
\mathrm{v}_{\text {ith }}=\bar{x}_{h} \alpha+\eta_{i t h}, \eta \sim \operatorname{iid}\left(0, \sigma_{\eta}^{2}\right) \text {, }
$$

where $\bar{x}_{h}$ is the mean of the time-varying explanatory variables for household $h, \alpha$ is the corresponding vector of coefficients, and $\eta$ is a random error term that is unrelated to $\bar{x}$ 's. The vector $\alpha$ is equal to zero if observed explanatory variables are uncorrelated with the random effects. The use of fixed effects techniques and Mundlak's approach also helps us to address potential problems of selection and endogeneity bias if selection and endogeneity bias are related to time-invariant unobserved factors (Wooldridge, 2002). Moreover, the estimation of the $\alpha$ 
parameters allows us to test for the relevance of the fixed effects via an F test (testing whether the estimated coefficients in vector $\alpha$ are jointly equal to zero). We rejected this null hypothesis, implying that controlling for the pseudo fixed effect is necessary to obtain consistent estimates.

$$
w_{i t h}=\alpha_{0}+\alpha_{1} \ln x_{h t}+\alpha_{3} k_{h t}+\alpha_{4} A_{h t}+v_{\text {ith }}
$$

Since the kinship variable is determined by bloodlines and marriage, one might expect it to be exogenous and not be correlated with the error term. However, this is not obviously true in light of omitted variables affecting both the number of external links of the household, resident household size as well as consumption choices. Moreover, to the extent that geographic distance affects requests for support, one would expect that migrants experience a lower family tax. For these reasons we explore several dimensions of potential endogeneity bias in what follows. ${ }^{11}$

The panel treatment should produce consistent estimates in case kinship is correlated with the (unobserved) time-invariant household fixed effects. However, there may be time-varying unobservables. To rule out that our results are an econometric artifact stemming from failure to control for unobserved heterogeneity or endogeneity we also estimate the kinship coefficient via a two stage least squares (2SLS) model, instrumenting for the size of the kinship network. ${ }^{12}$ Instrument choice is notoriously complex, and the literature offers little guidance as to what might be a proper instrument for the kinship variable. We extend the instrument matrix by including the average value of the kinship proxy in the neighborhood, assuming that this is correlated with the kinship proxy of the $i^{\text {th }}$ household, but not necessarily with consumption and savings decisions. We have also used lagged values of household's kinship network and obtained results that are qualitatively similar (results available on request).

We also consider the case where resident household size is endogenous. Earlier work on the old age pension in South Africa suggests household size responds to economic conditions, including 'income shocks' such as the receipt of a pension (Duflo, 2003; Adato et al., 2007; Klasen and Woolard 2008). In model specifications where household size is treated as 
endogenous, we extend the matrix of instruments by including the average household size in the neighborhood.

Table 1 about here

As mentioned, data are drawn from the 1993, 1998 and 2004 KwaZulu-Natal Income Dynamics Study. Data from all three rounds are used in the analysis below, and differences in sample size across models are due to data availability. Table 1 presents summary statistics. Our kinship proxy is constructed as follows. First, respondents were asked to list all people who lived at least 15 days in the year in the household. From this list we summed the number of relatives (grandparents, parents, aunts or uncles, siblings, cousins, nieces, nephews, etc.) that don't live under the same roof as the household head. We determine non-residence by the following question; 'Has he or she lived under this roof for more than 15 days of the last 30 days?'. Note that this is not a complete measure of the kin network - it only captures the subset of family members that actually lived in the household, or the subset of kin members with particularly close relations to the household. Notwithstanding this important qualification or caveat, we use the term "kin proxy" to refer to this variable in what follows. ${ }^{13}$

Our kinship variable is not a measure of the actual family tax burden, but rather captures potential pressure that could be exerted on the household by a subsample of the kin members. Measuring the actual size of the family tax, or even the relevant kin network, is fraught with difficulties. The average number of links in our sample is low, reflecting that it is only an incomplete measure of the total kinship network. Possibly it also captures the high prevalence of AIDS in the study region (Adato et al., 2007 refer to the 'incredibly high number of deaths in households' and mention 'stories about weekly funerals'). Nevertheless, since the kinship variable reflects links to other households, and given that the average household size is of about seven members, the total number of kin members depending on the household may be quite large. 
To explore the effect of kinship on spending we distinguish between different categories of consumption goods depending on the degree to which these goods are 'sharable.' Overall, our expenditure categories amount to more than $30 \%$ of annual household expenditures. The largest overall expenditures category was food, which captures over $40 \%$ of total expenditures (reflecting the low socio-economic status of the respondents - see endnote 9 for additional information about food expenditures).

Least sharable are expenditures for home improvement. Importantly, this variable does not include payments to increase the size of the house, which could be conflated as an in-kind transfer to kin members if larger houses enable households to accommodate more kin members. Instead, it captures expenditures for upgrading or restoring roofs, floors, doors, etc. On average this category amounts to $7.7 \%$ of expenditures of surveyed households. One approach for attenuating the family tax is, at the margin, to allocate more resources to this non-sharable good.

Next, we distinguish a category of goods that are somewhat sharable. These are goods that may possibly be carted off (and pawned or used) by kin members. For this purpose we use expenditure on furniture ( $8 \%$ of expenditures) and clothes (13\% of expenditures). Finally, we also have a good that is easy to cart off and that can readily be converted into moneyindividual items that can be easily traded or borrowed. Our proxy for sharable assets is expenditures on jewelry and watches. The theory predicts that in an effort to attenuate the family tax, households will, at the margin, respond to a larger kinship network by allocating more resources to 'home improvement' and less to 'jewels and watches.' The other goods, 'furniture' and 'clothes' represent an intermediate category. They are to some extent sharable so households should cut back expenditures on these goods as the extended family expands, but since these goods are less liquid we would expect a smaller evasive response.

We use the share of savings in current accounts, savings accounts, and stokvel (i.e., contributions to a local credit cooperative) as our measure of liquid financial assets. As a 
robustness analysis we have also considered the total stock of accumulated financial assets (and not the flow of savings divided by income) to capture that these assets are accumulated over various years and that the kinship variable is rather invariant over time. We have also varied the sub-categories of savings to be included in our overall savings variable to reflect that some savings forms are more liquid and accessible to kin members than others -Anderson and Baland (2002) suggest that stokvel may be used to protect savings from others. The results for these alternative savings variables are qualitatively similar, and we focus our presentation on the savings share results as this variable is most consistent with the expenditure share variables mentioned above.

As controls in our budget share and asset regressions we include (the logarithm of) total expenditures as a measure of resources available to the household. It is common in the literature on Engel demand curves to test for non-linearities in the relationship between budget shares and total expenditures. In some estimations, where we expect a 'threshold effect' (such as jewels and savings), we include a quadratic term for the expenditures variable in our model, but this term never affects the results for our kinship proxy. We also include a dummy for rural households (in rural areas most activities are related to agriculture), a measure of proximity to road infrastructure, the number of resident household members, and the average age of members in the household. ${ }^{14}$ Unfortunately we don't have enough data to account for the flows of transfers in the (kinship) network. But in some of the models we will include a dummy variable to indicate whether or not the household received remittances from family members elsewhere (this could be important as migrant preferences over expenditure of money they send home may affect actual expenditure patterns).

\section{Regression results}


Tables 2 to 6 report our main results (tests for validity of the instruments are reported at the bottom of each table) of the different estimators and specifications for each category of budget share. Throughout, we present the Mundlak model in column 1 and the IV results (addressing endogeneity of total expenditures and kinship) in column (2). We address the issues of endogeneity and heterogeneity together by estimating an IV model that includes household fixed effects in column (3). In column (4) we include squared expenditures as an extra control. In column (5) we treat household size as endogenous, and in column (6) we include a dummy to indicate whether the household receives remittances. Regardless of the model, the main results are consistent and support our conjecture.

Table 2 about here

Table 2 refers to expenditures on home improvement. The main coefficient of interest is the one associated with our kinship proxy. While this variable does not enter as statistically significant in the simple Mundlak model, it is consistently significant in the remaining five specifications (where the IV estimates turn out to be the preferred ones, see below). The estimated coefficients are positive, which is consistent with the hypothesis that compulsory sharing invites distortionary spending. Households with more close family members allocate a greater share of their expenditures towards the consumption of durables that cannot be shared. The calculated elasticity (estimated at sample means using model (5) hereafter) is a non trivial 0.85. An increase of $1 \%$ in the kinship variable is associated with an increase of $0.85 \%$ in expenditure for home improvement.

Results of the various overidentification tests (Sargan-Hansen), endogeneity tests (Wu Hausman) and instrument relevance tests are summarised at the bottom of the Tables. The test statistics refer to model (5), but the ones for the other 2SLS specifications are comparable and consistently support our econometric approach. We cannot reject the null hypothesis that expenditures, kinship and household size are endogenous variables, hence an IV estimation 
procedure is appropriate. The standard Sargan-Hansen overidentification test suggests our instruments for the kin network and household size can be excluded from the second stage (income variables are also appropriate instruments for expenditures, as well-established in the literature, but we suppress this test information). In all Tables, and for all specifications, we also reject the overidentification test of the instruments jointly tested. The relevance of the instruments is tested via both the underidentification test (Kleibergen-Paap LM statistic) as well as the partial $\mathrm{F}$ of the excluded instruments in the corresponding first-stage regression. We fail to reject the null hypothesis of underidentification in all models. Most of the F tests are above or fairly close to 10 (the smallest value is about 8 ), hence our estimates do not seem affected by weak identification bias (the appendix reports all first stage regressions. We also estimated all models via limited information maximum likelihood (LIML) and obtained similar results (available on request).

Tables $3 \& 4$ about here

Tables 3 and 4 report the estimated models for the case of "intermediate categories" furniture and clothes. These are durable and to some extent sharable assets. Again we find evidence consistent with the hypothesised evasive behavior, so now the estimated coefficient is of opposite sign. The greater the number of close relatives the smaller is expenditure in both categories. Both the IV and Fixed effect IV approach suggest increasing the number of close relatives is associated with less of such expenditures; the calculated elasticities are -0.78 and -2.3 for furniture and clothes respectively.

Table 5 about here

Table 5 summarises results for the asset that we consider most easily sharable. The estimated coefficient for the kinship proxy in the jewel equation is negative and statistically significant in all estimated models. Moreover, the response of jewels expenditures to pressure from close relatives seems high. The estimated elasticity is -1.33 so that a $1 \%$ increase in the 
number of close relatives is associated with a $1.3 \%$ reduction of jewel expenditures. Taken together, the evidence in Tables 3-5 is consistent with the view that households are unwilling to hold on to durable assets if they feel that such assets may be subject to forced sharing with others, and more so if the asset in question is more easily sharable.

Alternative explanations may be proposed for some of this evidence presented. Specifically, it can be argued that households with bigger kin networks may feel less need to self-insure (as they can rely on their kin), and as a result spend more on home improvements (and food), and less on jewels. We believe the evidence is more supportive of the family tax hypothesis than the alternative 'kin insurance' argument. Consider the results for clothing and furniture. Since these assets are potentially sharable (they can be picked up and taken from the household by kin and they can be traded or pawned), the family tax hypothesis predicts that larger kinship networks are associated with reduced expenditures. In crisp contrast, the explanation that mutual insurance frees up resources for consumption unambiguously predicts that consumption of furniture and appliances should increase in the size of the kin network. The results in Tables 3 and 4 support the family tax perspective but not the insurance view.

While the potential distortive effect of the family tax on consumption is in itself of interest to economists, its impact on savings and investment decisions are perhaps more relevant because of the dynamic implications. If compulsory sharing attenuates accumulation incentives, it could contribute to the creation of poverty traps (e.g. Carter and Barrett 2006). The regression results in Columns 1-4 of Table 6 are consistent with such an idea. The estimated coefficient for the kinship proxy is consistently negative and significant. The estimated elasticity is -1.24 , hence a $1 \%$ increase in the number of kinship links is associated with a $1.24 \%$ reduction in savings. This complements the macroeconomic perspective of Aiyagari (1994) who studied the implications of uninsured idiosyncratic risks for aggregate savings behavior due to a precautionary savings motive-another mechanism linking network access to savings. He finds 
that social insurance lowers savings, consistent with our micro-evidence (even if the mechanism is different). Translating such behavioral responses in standard growth-type models (e.g. BenDavid, 1998) would suggest that long-term income effects may result. If future research confirms that the behavioral response to 'moral economy' obligations exists, extended kinship systems may perpetuate poverty.

Table 6 about here

Perhaps households with more migrant members receive remittances, which may de facto affect budget allocations? We attempt to control for this and include a dummy that captures if the household receives remittances. The augmented model is reported in column (6) of Tables 26. The estimated coefficients for the kinship variable are not affected by this extra control. Moreover, the estimated coefficient for remittances is not significant for most models.

As a further robustness check we have re-run all regressions using expenditures per household member for the various categories, rather than the aggregate household expenditure measure. The qualitative results are identical (not reported, but available on request).

Finally, the number of kinship links and household members could be negatively correlated in a mechanical way: for a given total kinship network size (household members plus other kinship members), decreasing the number of household members increases the number of non-household kinship members. To explore this issue of collinearity we also regressed kinship on a number of variables including household size, finding that the latter variable never enters significantly (e.g., in a simple regression of kinship on household income and size, the t-value of the household size variable is only 0.39 ). This does not come as a surprise: the unconditional correlation between kinship and household size is only $0.006{ }^{15}$

\section{Kinship and income}


Next, we explore the impact of kinship on household income. Kinship ties may reduce savings or work effort so that in a symmetric Nash equilibrium every household's income is lower. In reality, of course, kin members are not identical, and the burden of supporting others asymmetrically rests on the shoulders of a subset of the kin network. Income levels probably determine whether households are on the giving or receiving end of the distribution. If so, an ambiguous relation between income and the size of the kinship network eventuates — depending on the balance between transfers received and given, as well as the impact on accumulation and investment decisions. We expect richer households to be unambiguously negatively affected by more extensive kinship obligations (these households are net transfer providers and also incur the incentive effect induced by the family tax). In contrast, for poorer households the net effect is ambiguous. Like their more wealthy counterparts they incur adverse incentive effects, but this may be offset by positive net transfers within the network.

To explore this issue we ran an interquintile regression model, regressing our measure of household resources (proxy for income) on the number of close relatives and our controls. This flexible approach allows us to explore whether the relation between income and kinship varies across quintiles of the income distribution. The results are reported in Table 7. Consistent with expectations we find qualitatively different kinship coefficients for the various income groups. Specifically, while there is always a negative association between income and kinship, our proxy increases monotonically as we consider higher income subsamples. Adverse effects of the extended family on income appear especially large for the top of the distribution.

Table 7 about here

Two final remarks and caveats are in order. First, the negative association between income and kinship need not indicate that households are worse off as their kin network expands. There are benefits to kin as well as costs. Second, the approach taken in this subsection is rough. Whether households are net receivers from (or providers to) the network depends on their 
income relative to that of their own kin members - rather than relative to the sample population. However, data to test this are not available.

\section{Discussion and Conclusions}

An important source of inspiration for this project was conversations with (African) colleagues, locked up in kinship obligations. For example, one of them drove a car that seemed extravagant in light of his salary. While we initially believed this was due to an unusual preference for expensive vehicles, or perhaps to status seeking, we soon learned that our colleague owned an expensive car to credibly signal to his kin that his residual resources for providing assistance were limited or non-existent. In our jargon, the car was a non-sharable asset.

A re-appraisal of the role of culture in development appears appropriate. The 'modernization approach' to development advanced in the 1950s argued that traditional societies cannot graduate smoothly into the industrial era unless they abandon traditional patterns of motivations, attitudes and values (e.g. Moore, 1963). This approach has been discredited, and gave way to another paradigm arguing that rural people in developing countries make efficient choices from a wide spectrum of contracts, taking into account their resource endowments and the conditions surrounding them (e.g. Schultz, 1964; Hayami and Otsuka, 1993). Our results suggest both perspectives may be correct. Poor people may be rationally responding to norms (as argued by Schultz and others), but some norms may be inimical to development (consistent with the modernization approach view).

In the absence of access to formal financial institutions, traditional sharing norms imply a safety net for the unlucky and less able. However, the classical 'efficiency-equity' tradeoff may also be relevant in the context of the moral economy. Specifically, traditional sharing norms may distort household decision-making with respect to spending and saving, inviting substitution of non-sharable for sharable durables. Moreover, compulsory sharing is correlated with reduced 
savings, and we present tentative evidence that the impact of sharing norms varies across income groups (with adverse incentive effects dominating positive transfer effects for the high-income subsample).

If compulsory sharing within the kinship network is so detrimental to the economic interests of individuals, why does it persist? While a full treatment is beyond the scope of this paper, several observations are relevant. First, it is not evident that forced solidarity is against the interests of individuals. We focus on the distortive effects of the kinship networks, but there are benefits too. People lacking access to formal insurance possibilities may support the arrangement when they are uncertain about the future distribution of income. Paying a family tax may be viewed as an acceptable risk premium. Second, persistence of forced solidarity may be explained by punishment in case of rule transgression. If such punishment is sufficiently costly, individuals would prefer to abide with the rules even if they expect to be consistently on the 'giving' end of the spectrum. It may be the case, then, that sharing within the kinship network is a dysfunctional remnant element from earlier institutional arrangements. 'The extended family [...] is an example of an institution which has many advantages in one stage of development but which may later become a drag on economic development' (Bauer and Yamey 1957: 64). On explanations as to why dysfunctional institutions may persist, refer to Arnott and Stiglitz (1991), Platteau (2000), Hoff and Sen (2006), and the social conflict theory of Acemoglu et al. (2005).

In case the costs of forced solidarity within kin networks exceed the benefits - an open question at this stage - it would be important to learn how to 'loosen' kinship ties. While the scope for policy intervention in this domain may appear limited, recent evidence actually suggests that something can be done. Di Falco and Bulte (2009) focus on adverse incentive effects for self-protection against weather shocks in the context of Ethiopia, and find that adverse kinship effects only materialise when access to formal financial services is lacking. That is, 
there may be substitution possibilities between formal and informal insurance mechanisms. If also true in the context of Kwazulu-Natal, then efforts to promote expansion of the financial system into remote and heretofore uncovered areas may have as a side effect that kinship obligations lose their force.

Is the mechanism identified in this study a unique African phenomenon, and does it explain underdevelopment in Africa? While the strength of kinship obligations in some Asian countries has been recognised by anthropologists, we are not aware of any non-African studies confirming or refuting our results. Theory does not help us much either. Acemoglu et al. (2005) distinguish between four different views on the origins and persistence of institutions. ${ }^{16}$ Differences between the impact of sharing norms in Africa and elsewhere, if any, may be due to several factors, including the size of the network, the strength of the sharing norm, and the distribution of income within the network. Our current understanding of how kinship sharing norms have evolved is not sufficiently advanced to endorse any specific theory to link kinship to African underdevelopment. ${ }^{17}$

We conclude by noting that more research on the cultural underpinnings of development is warranted. Future research on kinship, savings and income growth could usefully include asymmetric information (the visibility of income and the signal effects implied by different modes of spending). Moreover, extending the analysis by focusing on transfers within kin networks would be a logical next step, as would be a study on a non-African country where the kinship ties are known to be strong. Of course it would also be important to repeat the current analysis using a more complete measure of the kinship network. The current proxy is based on close relatives who actually spent some time in the household-it is clearly relevant to know whether these findings spill over to the kinship network at large. The material presented in this paper hopefully acts as an early step to trigger more work in this relevant domain. 
4. Barr et al. (2008) consider endogenous formation of risk sharing groups in an economic experiment and also

3. Other mechanisms may exist. There are the usual moral hazard problems associated with the provision of (mutual) insurance against contingencies. For example, Bauer and Yamey (1957, p. 66) write '... the [extended family] system ... minimises the inducement for people to improve their position because they can count on being provided with the means of subsistence at a level not very different from that of the majority of their kinsmen, including the energetic, thrifty and able.' Another avenue via which sharing norms may have adverse economic consequences is nepotism. If successful kinship members achieve positions of responsibility they may be expected to provide jobs for less fortunate (and possibly less qualified) relatives. But if nepotism is costly for organizations and firms, and can be anticipated, the odds that a kinship member will actually be promoted to positions of authority will decline (or the terms associated with the position will deteriorate). For a theoretical model highlighting entry barriers for kin members in a modernizing society, refer to Hoff and Sen (2006) and for empirical work on nepotism in Ghana, refer to Collier and Garg (1999). conclude 'genetically related individuals tend to distrust one another and so do not group when enforcement depends on intrinsic motivations alone'.

5. For a critical appraisal of the concept of social capital, and how it has been interpreted and used in the social sciences, refer to Fine (2002, 2003).

6. Moreover, Carter and Maluccio (2003) present evidence suggesting that structural social capital insures households against (idiosyncratic) economic shocks, where the coping capacity of households is measured by the nutritional status of children (height-for-age $\mathrm{z}$ scores of young children).

7. KIDS 1998 and 2004 was a collaborative project between researchers at the International Food Policy Research Institute (IFPRI), the University of Natal, and the University of Wisconsin, but to accommodate new areas of interest new partners were included in the 2004 wave (London School of Hygiene and Tropical Medicine, and the Norwegian Institute of Urban and Regional Studies).

8. This includes delaying the start-up of new households by young adults, dissolution of existing households, and consolidation as some individuals return to their parents (or other family members) in response to economic conditions.

9. In a separate set of regressions we have also examined whether the 'durability of goods' matters. Intuitively, non-durability of certain goods may be an alternative approach to avoid the family tax-goods used up in consumption cannot be shared. For this purpose we regressed the share of expenditures on food on kinship and a series of controls. Consistent with the hypothesis we find some evidence that per capita consumption of food increases as the kinship network is larger. These results are available on request.

10. We also explored including a quadratic term for the log of total expenditure, and found this did not affect the main results.

11. See Angelucci et al. (2009) for an analysis of the relation between poverty and inequality in Mexican villages, and the structure of local extended family networks.

12. We also explored the consequences of controlling for spatial effects. The households in the database belong to 63 different neighborhoods. Spatial or neighborhood effects may be relevant because households from a certain area could simultaneously have a large kinship network and, say, low consumption of jewels or low levels of savings. We adopted a random-effects 2SLS model (Baltagi, 2008) to capture the concern of systematic variation in the structure of families across (but not within) neighborhoods. The qualitative results are very consistent with the ones presented (available from the authors on request).

13. It is not clear whether respondents also included family members of the household head's spouse. This implies that we measure kinship with noise, which will bias our estimates towards zero. An important caveat is the following: it is possible that the extent of co-residency varies with income (where especially the poor live together). This could be another reason why our kin variable may be endogenously determined.

14. Unfortunately the level of education was not measured in a consistent manner across the three waves, so we cannot use education as a control (or instrument). However, education was measured consistently in the 1993 
and 1998 waves, and when we restrict the analysis to these two waves and include education as an extra control, all our results go through (details available on request).

15. We also tried a robustness analysis where we first regressed household size on kinship, and then use the residuals from this auxiliary regression to capture the role of household size in a system that explains expenditures. This does not affect the results (results available on request).

16. These are (i) the efficient institutions view, spelling out that societies choose the institutions that maximise social surplus, (ii) the social conflict view, arguing that institutions are chosen that maximise the rents of a (powerful) sub-group in society, (iii) the beliefs view, recognizing that societies have different views about what is best for society, and (iv) the incidental institutions view, emphasizing the development of institutions as a by-product of other social interactions.

17. But of course anthropological thinking provides several avenues for speculation. For example, sharing within family networks is an aspect of what Bledsoe (2002) terms the "wealth in people" system. Where labour is in shorter supply than land (as it is historically true across most of hoe-cultivating Sub-Saharan Africa) having large networks of needy dependents is an encashable agrarian asset (they turn out on your farm when needed). But, and as analyzed in this paper, along with it goes the kin's conviction that they can claim subsistence as needed - supporting a common cultural presumption that family assets are "common property" (Bledsoe 2002). If so, the "dark side of social capital" as analyzed on these pages is a distinctive African issue, driven by the agrarian system in which human labour has prevailed over ploughs and oxen. See also Goody and Tambiah (1973) for a comparative analysis of distinct-typical Asian and African family property regimes based on the plough/hoe contrast.

\section{References}

Acemoglu D., Johnson, S. and Robinson, J. (2005) Institutions as the fundamental cause of longterm growth, in: P. Aghion and S. Durlauf (eds.). Handbook of Economic Growth, (Amsterdam: North Holland), pp. 385-472.

Adato, M., Carter, M. and .May, J. (2006) Exploring poverty traps and social exclusion in South Africa using qualitative and quantitative data. Journal of Development Studies, 42(2), pp 226-247.

Adato, M., Lund, F. and Mhlongo, P. (2007) Methodological innovations in research on the dynamics of poverty: A longitudinal study in Kwazulu-Natal, South Africa. World Development, 35(2), pp. 247-263.

Aiyagari, S. (1994) Uninsured idiosyncratic risk and aggregate saving. Quarterly Journal of Economics, 109(3), pp. 659-684.

Anderson, S. and Baland, J.M. (2002) The economics of roscas and intrahousehold resource allocation. Quarterly Journal of Economics, 117(3), pp. 963-995.

Angelucci, M., de Giorgi, G. Rangel, M. and Rasul, I. (2009) Village economies and the structure of extended family networks. The B.E. Journal of Economic Analysis \& Policy (1) (Contributions), article 44

Arnott, R. and Stiglitz, J. (1991) Moral hazard and nonmarket institutions: Dysfunctional crowding out or peer monitoring? American Economic Review, 81(1), pp. 179-190. 
Baland, J-M., Guirkinger, C. and Mali, C. (2009) Pretending to be poor: Borrowing to escape forced solidarity in Cameroon. Economic Dynamics and Cultural Change, In Press

Barr, A., Dekker, M. and Fafchamps, M. (2008). Risk sharing relations and enforcement mechanisms." CSAE, Oxford University, mimeo

Barr, A. and Genicot, G. (2008). Risk sharing, commitment and information: An experimental analysis. Journal of the European Economic Association, 6(6), pp. 1151-1185.

Bauer, P. and Yamey, B. (1957). The economics of under-developed countries. (Cambridge: Cambridge University Press).

Ben-David, D. (1998). Convergence clubs and subsistence economies. Journal of Development Economics 55 (1), pp. 153-159.

Bledsoe, C. (2002). Women and marriage in Kpelle society. (Palo Alto: Stanford University Press).

Blundell R, Pashardes, P. and Weber G. (1993) What do we learn about consumer demand patterns from micro data? American Economic Review, 83(3), pp. 570-597.

Carter, M.R. and Castillo, M. (2002) The economic impacts of altruism, trust and reciprocity: An experimental approach to social capital. Staff Paper 448 (Madison: University of WisconsinMadison, Dept. of Agricultural \& Applied Economics)

Carter, M.R. and Castillo, M. (2009). Trustworthiness and social capital in South Africa: Analysis of actual living standards data and artefactual field experiments. Working Paper (Madison: University of Wisconsin-Madison, Dept. of Agricultural \& Applied Economics).

Carter, M.R. and C. Barrett (2006). The economics of poverty traps and persistent poverty: An asset-based approach. Journal of Development Studies, 42(2), pp. 178-199.

Carter, M.R. and Maluccio, J.A. (2003) Social capital and coping with economic shocks: An analysis of stunting of South African children. World Development 31(7), pp. 1147-1163.

Chantarat, S. and Barrett, C.B. (2008) Social network capital: Economic mobility and poverty traps. Working Paper (Ithaca: Cornell University).

Coate, S. and Ravallion, M. (1993) Reciprocity without commitment: Characterization of informal insurance arrangements. Journal of Development Economics, 40(1), pp. 1-24.

Collier, P. and Garg, A. (1999) On kin-groups and wages in the Ghanaian labor market. Oxford Bulletin of Economics and Statistics, 61(2), pp. 133-157. 
Di Falco, S. and Bulte, E.H. (2009) Social capital and weather shocks in Ethiopia: Climate change and culturally-induced poverty traps. Working Paper (London: London School of Economics).

Duflo E. (2003) Grandmothers and granddaughters: Old-age pensions and intrahousehold allocation in South Africa. The World Bank Economic Review, 17(1), pp. 1-25.

Du Toit, A. and Neves, D. (2009) Trading on a grant: Integrating formal and informal social protection in post-apartheid migrant network. BWPI Working paper 75 (Manchester: Brooks World Poverty Institute).

Fafchamps, M. (1992). Solidarity networks in pre-industrial societies: Rational peasants in a moral economy. Economic Development and Cultural Change 41(2), pp. 147-173.

Fafchamps, M. and Lund, S. (2003) Risk sharing networks in rural Philippines. Journal of Development Studies, 71(2), pp. 261-287.

Fine, B. (2003) Social capital: The World Bank's fungible friend. Journal of Agrarian Change, 3(4), pp. 586-603.

Fine, B. (2002) It ain't social, it ain't capital and it ain't Africa. Studia Africana 13, pp. 18-33.

Fortes, M. (1969). Kinship and the social order: The legacy of Lewis Henry Morgan (Aldine: Chicago).

Foster, A. and Rosenzweig, M. (2001) Imperfect commitment, altruism, and the family: Evidence from transfer behavior in low-income rural areas. Review of Economics and Statistics, 83(3), 389-407.

Genicot, G. and Ray, D. (2003) Group Formation in risk-sharing arrangements. Review of Economic Studies, 70(1), pp. 87-113.

Goody, J. and Tambiah, S. (1973). Bridewealth and Dowry (London: Cambridge University Press).

Gulliver, P.H. (1971) Neighbours and Networks: The Idiom of Kinship in Social Action among the Ndendeuli of Tanzania (Berkeley: University of California Press).

Hadad, L. and Maluccio, J. (2003) Trust, membership in groups and household welfare: Evidence from Kwazulu-Natal, South Africa. Economic Development and Cultural Change, 51(3), pp. 573-601.

Hoff, K., and Sen, A. (2006) The kin system as a poverty trap, in: S, Bowles, S. Durlauf and K. Hoff (eds.) Poverty Traps (Princeton: Princeton University Press). 
Kennedy, P. (1988) African Capitalism: The Struggle for Ascendancy (Cambridge: Cambridge University Press).

Klasen, S. and Woolard, I. (2008) Surviving unemployment without state support: Unemployment and household formation in South Africa. Journal of African Economies, 18(1), pp. 1-51.

Kraay, A. and Raddatz, C. (2007) Poverty traps, aid, and growth. Journal of Development Economics, 82(2), pp. 315-347.

Lewis, W. (1955). The theory of economic growth (London: George Allen \& Unwin).

Ligon, E., Thomas, J. and Worrall, T. (2002) Mutual insurance and limited commitment: Theory and evidence in village economies. Review of Economic Studies, 69(1), pp. 115-139.

Maluccio, J., Haddad, L. and May, J. (2000) Social capital and household welfare in South Africa, 1993-98. Journal of Development Studies, 36(6), pp. 54-81.

May, J., Aguero, J. Carter, M. and Timaes, I. (2006). The Kwazulu-Natal Income Dynamics Study (KIDS) $3^{\text {rd }}$ wave: Methods, first findings and an agenda for future research. Working Paper (Madison: University of Wisconsin-Madison, Dept. of Agricultural \& Applied Economics).

McCallum, B.T. (1972) Relative asymptotic bias from errors of omission and measurement. Econometrica, 40(4), pp. 757-759.

Moore, W.E. (1963) Social Change (New York: Prentice-Hall).

Platteau, J.P. (1991) Traditional systems of social security and hunger insurance: Past achievements and modern challenges, in: E. Ahmad, J. Dreze, J. Hills, and A. Sen (eds.) Social Security in Developing Countries (Oxford: Clarendon Press), pp. 112-170.

Platteau, J.P. (2000) Institutions, Social Norms and Economic Development (Amsterdam: Harwood)

Rosenzweig, M.R. (1988) Risk, implicit contracts and the family in rural areas of low-income countries. Economic Journal, 98(393), pp. 1148-1170.

Schultz, T.W. (1964) Transforming Traditional Agriculture (New Haven: Yale University Press).

Scott, J. (1976) The Moral Economy of the Peasant: Rebellion and Subsistence in Southeast Asia (New Haven: Yale University Press).

Townsend, R. (1994) Risk and insurance in village India. Econometrica, 62(3), pp. 539-591. 
Udry, C. (1994). Risk and insurance in a rural credit market: An empirical investigation in Northern Nigeria. Review of Economic Studies, 61(3), pp. 495-526. 
Table 1: Definition and summary of the variables

\begin{tabular}{|c|c|c|c|c|}
\hline & Mean & Std Dev & Min & Max \\
\hline $\begin{array}{l}\text { Ln (expenditures): } \\
\text { Total expenditure in Rand } \\
\text { ( } 1 \text { USD }=6.02 \text { Rand) }\end{array}$ & 7.98 & 1.438 & 2.3 & 13.71 \\
\hline $\begin{array}{l}\text { Kin proxy: } \\
\text { (see definition in text) }\end{array}$ & 1.7 & 2.621 & 0 & 20 \\
\hline $\begin{array}{l}\text { Rural (dummy, } 1=\text { yes; } 0=\text { urban): } \\
\text { If main source of income is from } \\
\text { agriculture }\end{array}$ & 0.526 & 0.499 & 0 & 1 \\
\hline $\begin{array}{l}\text { Proximity: } \\
\text { Proximity to infrastructure }\end{array}$ & 2.578 & 0.603 & 1 & 3 \\
\hline $\begin{array}{l}\text { Household size: } \\
\text { Number of resident member of the } \\
\text { household } \\
\text { Age : } \\
\text { Average age of the household }\end{array}$ & $\begin{array}{r}7.987 \\
23.014\end{array}$ & 8.003 & 5.013 & 32 \\
\hline $\begin{array}{l}\text { Remittances (dummy: } 1=\text { yes): } \\
\text { If household receive remittances } \\
\text { from migrated household members }\end{array}$ & 0.353 & 0.478 & 0 & 1 \\
\hline $\begin{array}{l}\text { Durable and non-sharable - Home } \\
\text { improvements: budget share } \\
\text { allocated to home improvement in } \\
\text { rand }\end{array}$ & 0.077 & 0.149 & 0 & 0.9 \\
\hline $\begin{array}{l}\text { Durable }- \text { semi sharable }- \\
\text { Furniture: budget share allocate to } \\
\text { furniture in rand }\end{array}$ & 0.092 & 0.192 & 0 & 0.99 \\
\hline $\begin{array}{l}\text { Semi durable and sharable - } \\
\text { Clothes: budget share allocated to } \\
\text { clothes in rand }\end{array}$ & 0.131 & 0.2 & 0 & 0.96 \\
\hline $\begin{array}{l}\text { Durable and sharable assets - } \\
\text { Jewels: budget share allocated to } \\
\text { jewels and watches in rand }\end{array}$ & 0.018 & 0.046 & 0 & 0.746 \\
\hline $\begin{array}{l}\text { Assets: } \\
\text { Share of Liquid assets, savings, } \\
\text { investments in rand }\end{array}$ & 0.032 & 0.072 & 0 & 0.99 \\
\hline
\end{tabular}


Table 2 Home improvement and Kinship proxy

\begin{tabular}{|c|c|c|c|c|c|c|}
\hline & $\begin{array}{c}\text { Fixed Effect } \\
\text { (1) }\end{array}$ & $\begin{array}{l}\text { IV } \\
\text { (2) }\end{array}$ & $\begin{array}{c}\text { Fixed Effect } \\
\text { IV } \\
\text { (3) }\end{array}$ & $\begin{array}{c}\text { Fixed } \\
\text { Effects IV } \\
(4)\end{array}$ & $\begin{array}{c}\text { Fixed Effects } \\
\text { IV } \\
\text { (5) }\end{array}$ & $\begin{array}{c}\text { Fixed Effects } \\
\text { IV } \\
(6)\end{array}$ \\
\hline Kin proxy & $\begin{array}{l}-0.00174 \\
(0.00174)\end{array}$ & $\begin{array}{c}0.0290 * * \\
(0.0139)\end{array}$ & $\begin{array}{l}0.0296 * \\
(0.0156)\end{array}$ & $\begin{array}{c}0.0164 * \\
(0.010)\end{array}$ & $\begin{array}{c}0.0352 * * \\
(0.0156)\end{array}$ & $\begin{array}{c}0.0313 * * \\
(0.0138)\end{array}$ \\
\hline Ln (Exp) & $\begin{array}{c}0.00550 * * \\
(0.00265)\end{array}$ & $\begin{array}{l}-0.0114 \\
(0.0131)\end{array}$ & $\begin{array}{l}-0.0126 \\
(0.0193)\end{array}$ & $\begin{array}{c}-0.264 * * \\
(0.130)\end{array}$ & $\begin{array}{c}0.112 \\
(0.175)\end{array}$ & $\begin{array}{c}0.115 \\
(0.152)\end{array}$ \\
\hline $\operatorname{Ln}(\operatorname{Exp})^{2}$ & & & & $0.0142 * *$ & -0.00621 & -0.00637 \\
\hline & & & & $(0.00689)$ & (0.00999) & $(0.00864)$ \\
\hline Hh size & $\begin{array}{l}-0.000945 \\
(0.00103)\end{array}$ & $\begin{array}{c}0.00000275 \\
(0.00125)\end{array}$ & $\begin{array}{l}-0.00125 \\
(0.00120)\end{array}$ & $\begin{array}{l}-0.000524 \\
(0.00156)\end{array}$ & $\begin{array}{l}-0.00254 \\
(0.00743)\end{array}$ & $\begin{array}{l}-0.00170 \\
(0.00631)\end{array}$ \\
\hline Proximity & $\begin{array}{l}-0.00816 \\
(0.00888)\end{array}$ & $\begin{array}{c}-0.0131 \\
(0.00913)\end{array}$ & $\begin{array}{l}-0.0118 \\
(0.0101)\end{array}$ & $\begin{array}{l}-0.0147 \\
(0.0115)\end{array}$ & $\begin{array}{l}-0.0150 \\
(0.0107)\end{array}$ & $\begin{array}{c}-0.0131 \\
(0.00955)\end{array}$ \\
\hline Rural & $\begin{array}{c}0.0142 \\
(0.00864)\end{array}$ & $\begin{array}{l}-0.0197 \\
(0.0165)\end{array}$ & $\begin{array}{c}-0.00770 \\
(0.0143)\end{array}$ & $\begin{array}{c}0.0136 \\
(0.0156)\end{array}$ & $\begin{array}{l}-0.0125 \\
(0.0148)\end{array}$ & $\begin{array}{c}-0.00530 \\
(0.0127)\end{array}$ \\
\hline Age & $\begin{array}{c}0.00148 \\
(0.00174)\end{array}$ & $\begin{array}{l}0.0110 * * \\
(0.00512)\end{array}$ & $\begin{array}{c}0.0140 * \\
(0.00769)\end{array}$ & & $\begin{array}{l}0.0195 * * \\
(0.00911)\end{array}$ & $\begin{array}{l}0.0180 * * \\
(0.00799)\end{array}$ \\
\hline $\mathrm{Age}^{\wedge} 2$ & -0.0000251 & $-0.000132 * *$ & $-0.000192 *$ & & $-0.000278^{*}$ & $-0.000254 * *$ \\
\hline Remittances & $(0.0000317)$ & $(0.0000651)$ & $(0.000114)$ & & $(0.000149)$ & $\begin{array}{c}(0.000128) \\
-0.0370 * * * \\
(0.0140)\end{array}$ \\
\hline Constant & $\begin{array}{l}0.00609 \\
(0.0387)\end{array}$ & $\begin{array}{c}-0.0442 \\
(0.156)\end{array}$ & $\begin{array}{c}-0.0648 \\
(0.246)\end{array}$ & $\begin{array}{l}1.238 * * \\
(0.584)\end{array}$ & $\begin{array}{l}-0.739 \\
(0.778)\end{array}$ & $\begin{array}{l}-0.719 \\
(0.662)\end{array}$ \\
\hline \multicolumn{7}{|c|}{$\begin{array}{l}\mathrm{N}: 1326 . \text { Test results for model (5). Endogeneity Test (Wu-Hausman } \mathrm{F} \text { test): 3.2898; } \mathrm{F}(3,1312): p \text {-value }=0.02 ; \\
\text { Sargan statistic (overidentification test of instruments): } p \text {-val }=0.74 ; \text { Test of excluded instruments }(\text { for Kin,Ln, } \\
\text { Expenditure, household size, respectively): } \mathrm{F}=8.03, p \text {-value }=0 ; \mathrm{F}=12.51, p \text {-value }=0 ; \mathrm{F}=30.54, p \text {-value }=0 . \\
\text { Kleibergen-Paap Wald rk LM statistic: } 11.62, p \text {-value: } 0.003 \text {. Standard errors in parentheses } * p<0.10, * * p<0.05 \text {, } \\
* * * p<0.01\end{array}$} \\
\hline
\end{tabular}


Table 3 Furniture and Kinship Proxy

\begin{tabular}{|c|c|c|c|c|c|c|}
\hline & $\begin{array}{c}\text { Fixed Effect } \\
(1) \\
\end{array}$ & (2) & $\begin{array}{c}\text { Fixed Effect } \\
\text { IV } \\
(3) \\
\end{array}$ & $\begin{array}{c}\text { Fixed Effects } \\
\text { IV } \\
\text { (4) } \\
\end{array}$ & $\begin{array}{c}\text { Fixed Effects } \\
\text { IV } \\
(5) \\
\end{array}$ & $\begin{array}{c}\text { Fixed Effects } \\
\text { IV } \\
(6) \\
\end{array}$ \\
\hline Kin proxy & $\begin{array}{c}-0.00511^{* *} \\
(0.00243)\end{array}$ & $\begin{array}{c}-0.0356 * * * \\
(0.0137)\end{array}$ & $\begin{array}{c}-0.0356 * * * \\
(0.0138)\end{array}$ & $\begin{array}{c}-0.0423 * * * \\
(0.0150)\end{array}$ & $\begin{array}{c}-0.0603 \\
(0.0516)\end{array}$ & $\begin{array}{c}-0.0602 \\
(0.0484)\end{array}$ \\
\hline Ln (Exp) & $\begin{array}{c}-0.0277 * * * \\
(0.00623)\end{array}$ & $\begin{array}{c}-0.0619 * * * \\
(0.0154)\end{array}$ & $\begin{array}{c}-0.0858 * * * \\
(0.0182)\end{array}$ & $\begin{array}{c}-0.0772 * * * \\
(0.0194)\end{array}$ & $\begin{array}{c}-0.109 * * * \\
(0.0366)\end{array}$ & $\begin{array}{c}-0.109 * * * \\
(0.0346)\end{array}$ \\
\hline $\operatorname{Ln}(\operatorname{Exp})^{2}$ & & & & $\begin{array}{c}0.0272 \\
(0.0277)\end{array}$ & $\begin{array}{c}0.0291 * * * \\
(0.0112)\end{array}$ & $\begin{array}{c}0.0291 * * * \\
(0.0107)\end{array}$ \\
\hline $\begin{array}{l}\text { Household } \\
\text { size }\end{array}$ & $\begin{array}{c}0.00272 \\
(0.00173)\end{array}$ & $0.00570 * * *$ & $0.00533 * * *$ & (0.00289) & 0.00936 & $(0.0131)$ \\
\hline Proximity & $\begin{array}{r}-0.00470 \\
(0.0133)\end{array}$ & $\begin{array}{c}-0.00345 \\
(0.0147)\end{array}$ & $\begin{array}{l}0.00122 \\
(0.0151)\end{array}$ & $\begin{array}{l}-0.00967 \\
(0.0190)\end{array}$ & $\begin{array}{r}-0.00952 \\
(0.0169)\end{array}$ & $\begin{array}{r}-0.00992 \\
(0.0165)\end{array}$ \\
\hline Rural & $\begin{array}{c}-0.0400 * * * \\
(0.0126)\end{array}$ & $\begin{array}{l}-0.0163 \\
(0.0198)\end{array}$ & $\begin{array}{l}-0.0165 \\
(0.0196)\end{array}$ & $\begin{array}{c}0.0117 \\
(0.0360)\end{array}$ & $\begin{array}{c}0.0151 \\
(0.0377)\end{array}$ & $\begin{array}{c}0.0137 \\
(0.0352)\end{array}$ \\
\hline Age & $\begin{array}{c}-0.000805 \\
(0.00136)\end{array}$ & $\begin{array}{l}-0.00204 \\
(0.00183)\end{array}$ & $\begin{array}{l}-0.00129 \\
(0.00182)\end{array}$ & $\begin{array}{l}-0.00239 \\
(0.00205)\end{array}$ & $\begin{array}{l}-0.00334 \\
(0.00445)\end{array}$ & $\begin{array}{l}-0.00337 \\
(0.00405)\end{array}$ \\
\hline $\mathrm{Age}^{\wedge} 2$ & $\begin{array}{c}0.000144 \\
(0.0000907)\end{array}$ & $\begin{array}{c}0.000139 \\
(0.0000971)\end{array}$ & $\begin{array}{c}0.000132 \\
(0.0000978)\end{array}$ & $\begin{array}{c}0.000161 \\
(0.000102)\end{array}$ & $\begin{array}{c}0.000140 \\
(0.000176)\end{array}$ & $\begin{array}{c}0.000140 \\
(0.000173)\end{array}$ \\
\hline Remittances & & & & & & $\begin{array}{c}0.0112 \\
(0.0190)\end{array}$ \\
\hline Constant & $\begin{array}{c}0.355^{* * *} * \\
(0.0680) \\
\end{array}$ & $\begin{array}{c}0.732 * * * \\
(0.152) \\
\end{array}$ & $\begin{array}{c}0.957 * * * \\
(0.181)\end{array}$ & $\begin{array}{c}0.908 * * * \\
(0.182)\end{array}$ & $\begin{array}{c}1.219 * * * \\
(0.380)\end{array}$ & $\begin{array}{c}1.215 * * * \\
(0.357) \\
\end{array}$ \\
\hline \multicolumn{7}{|c|}{$\begin{array}{l}\mathrm{N}: 825 . \text { Test statistics for model (5). Endogeneity Wu-Hausman } \mathrm{F} \text { test (for Ln Expenditure,Kinship and Household } \\
\text { size): } 2.6, \mathrm{~F}(3,797) p \text {-value }=0.047 \text {; Sargan statistic (overidentification test of all instruments): } p \text {-value }=0.9 \text {; } \\
\text { Test of excluded instruments (for kin, Ln Expenditure, Household size, respectively): } \mathrm{F}=9.22, p \text {-value=0; } \mathrm{F}= \\
\text { 43.31, } p \text {-value }=0 ; \mathrm{F}=33, p \text {-value }=0 \text {. Kleibergen-Paap Wald rk LM statistic: } 11.6, p \text {-value: } 0.003 \text {. } \\
\text { Standard errors in parentheses } p<0.10, * * p<0.05, * * * p<0.01\end{array}$} \\
\hline
\end{tabular}


Table 4 Clothing and Kinship Proxy

\begin{tabular}{|c|c|c|c|c|c|c|}
\hline & $\begin{array}{c}\text { Fixed Effect } \\
\text { (1) }\end{array}$ & $\begin{array}{l}\text { IV } \\
\text { (2) }\end{array}$ & $\begin{array}{c}\text { Fixed Effect } \\
\text { IV } \\
\text { (3) }\end{array}$ & $\begin{array}{c}\text { Fixed Effects } \\
\text { IV } \\
\text { (4) }\end{array}$ & $\begin{array}{c}\text { Fixed Effects } \\
\text { IV } \\
\text { (5) }\end{array}$ & $\begin{array}{c}\text { Fixed Effects } \\
\text { IV } \\
(6)\end{array}$ \\
\hline Kin proxy & $\begin{array}{c}-0.0135 * * * \\
(0.00447)\end{array}$ & $\begin{array}{c}-0.129 * * * \\
(0.0429)\end{array}$ & $\begin{array}{c}-0.122 * * * \\
(0.0422)\end{array}$ & $\begin{array}{l}-0.0183 \\
(0.0435)\end{array}$ & $\begin{array}{c}-0.177 * * \\
(0.0781)\end{array}$ & $\begin{array}{c}-0.179 * * \\
(0.0785)\end{array}$ \\
\hline Ln (Exp) & $\begin{array}{c}-0.206 * * * \\
(0.0344)\end{array}$ & $\begin{array}{c}-0.362 * * * \\
(0.0703)\end{array}$ & $\begin{array}{c}-0.378 * * * \\
(0.0738)\end{array}$ & $\begin{array}{c}-2.807 * * \\
(1.114)\end{array}$ & $\begin{array}{c}-0.424 * * * \\
(0.0954)\end{array}$ & $\begin{array}{c}-0.423 * * * \\
(0.0956)\end{array}$ \\
\hline $\operatorname{Ln}(\operatorname{Exp})^{2}$ & & & & $\begin{array}{l}0.137 * * \\
(0.0620)\end{array}$ & $\begin{array}{l}0.115 * * * \\
(0.0310)\end{array}$ & $\begin{array}{c}0.114 * * * \\
(0.0311)\end{array}$ \\
\hline Hh size & $\begin{array}{c}0.00124 \\
(0.00399)\end{array}$ & $\begin{array}{c}0.0103 \\
(0.00679)\end{array}$ & $\begin{array}{c}0.0111 \\
(0.00704)\end{array}$ & $\begin{array}{c}0.00698 \\
(0.00552)\end{array}$ & $\begin{array}{l}0.00540 \\
(0.0221)\end{array}$ & $\begin{array}{l}0.00668 \\
(0.0222)\end{array}$ \\
\hline Proximity & $\begin{array}{l}-0.0178 \\
(0.0432)\end{array}$ & $\begin{array}{c}0.0124 \\
(0.0541)\end{array}$ & $\begin{array}{c}0.0150 \\
(0.0544)\end{array}$ & $\begin{array}{l}-0.0144 \\
(0.0433)\end{array}$ & $\begin{array}{l}-0.0291 \\
(0.0524)\end{array}$ & $\begin{array}{l}-0.0311 \\
(0.0529)\end{array}$ \\
\hline Rural & $\begin{array}{c}-0.114 * * * \\
(0.0314)\end{array}$ & $\begin{array}{c}0.0192 \\
(0.0649)\end{array}$ & $\begin{array}{c}0.0264 \\
(0.0628)\end{array}$ & $\begin{array}{c}0.106 \\
(0.0648)\end{array}$ & $\begin{array}{c}0.111 \\
(0.0915)\end{array}$ & $\begin{array}{c}0.106 \\
(0.0918)\end{array}$ \\
\hline Age & $\begin{array}{c}0.00991 * * \\
(0.00410)\end{array}$ & $\begin{array}{c}0.00831 \\
(0.00557)\end{array}$ & $\begin{array}{c}0.00884 \\
(0.00544)\end{array}$ & $\begin{array}{c}0.00567 \\
(0.00449)\end{array}$ & $\begin{array}{c}0.00646 \\
(0.00734)\end{array}$ & $\begin{array}{c}0.00603 \\
(0.00737)\end{array}$ \\
\hline $\operatorname{Age}^{\wedge} 2$ & $\begin{array}{c}-0.000585^{* *} \\
(0.000260)\end{array}$ & $\begin{array}{l}-0.000611 \\
(0.000454)\end{array}$ & $\begin{array}{l}-0.000586 \\
(0.000427)\end{array}$ & $\begin{array}{l}-0.000110 \\
(0.000329)\end{array}$ & $\begin{array}{l}-0.000145 \\
(0.000516)\end{array}$ & $\begin{array}{c}-0.000136 \\
(0.000518)\end{array}$ \\
\hline Remittances & & & & & & $\begin{array}{c}0.0255 \\
(0.0529)\end{array}$ \\
\hline Constant & $\begin{array}{c}2.289 * * * \\
(0.363)\end{array}$ & $\begin{array}{c}3.929 * * * \\
(0.681)\end{array}$ & $\begin{array}{c}4.042 * * * \\
(0.724)\end{array}$ & $\begin{array}{c}14.17 * * * \\
(4.787)\end{array}$ & $\begin{array}{c}4.725 * * * \\
(1.002)\end{array}$ & $\begin{array}{c}4.711 * * * \\
(1.003)\end{array}$ \\
\hline \multicolumn{7}{|c|}{$\begin{array}{l}\text { N: 579. Test statistics for model (5). Endogeneity test (Wu-Hausman } \mathrm{F} \text { test): } 17.56, \mathrm{~F}(3,565), p \text {-value }=0 \text {. } \\
\text { Sargan statistic (overidentification test of all instruments): } p \text {-value }=0.32 \text {. Test of excluded instruments (for Kin, } \\
\text { Ln Expenditure, Household size respectively): } \mathrm{F}=7.03, p \text {-value=0; } \mathrm{F}=25.06, p \text {-value }=0 ; \mathrm{F}=19.83, p \text {-value }=0 \text {. } \\
\text { Kleibergen-Paap Wald rk LM statistic: } 11.8, p \text {-value: } 0.0026 \text { Standard errors in parentheses } p<0.10, * * p<0.05 \text {, } \\
* * * p<0.01\end{array}$} \\
\hline
\end{tabular}


Table 5 Jewels and Kinship Proxy

\begin{tabular}{|c|c|c|c|c|c|c|}
\hline & Fixed Effect & IV & $\begin{array}{c}\text { Fixed Effect } \\
\text { IV }\end{array}$ & $\begin{array}{c}\text { Fixed } \\
\text { Effects IV }\end{array}$ & $\begin{array}{c}\text { Fixed Effects } \\
\text { IV }\end{array}$ & $\begin{array}{l}\text { Fixed } \\
\text { Effects } \\
\text { IV } \\
(6)\end{array}$ \\
\hline Kin proxy & $\begin{array}{c}-0.00000458 \\
(0.000800)\end{array}$ & $\begin{array}{c}-0.0159 * * * \\
(0.00489)\end{array}$ & $\begin{array}{c}-0.0119 * * \\
(0.00514)\end{array}$ & $\begin{array}{c}-0.0549 * * * \\
(0.0175)\end{array}$ & $\begin{array}{l}-0.0141^{*} \\
(0.00801)\end{array}$ & $\begin{array}{c}-0.014^{*} \\
(0.00808)\end{array}$ \\
\hline $\operatorname{Ln}(\exp )$ & $\begin{array}{c}-0.00663 * * * \\
(0.00132)\end{array}$ & $\begin{array}{c}-0.0279 * * * \\
(0.00701)\end{array}$ & $\begin{array}{c}-0.0386 * * * \\
(0.0102)\end{array}$ & $\begin{array}{c}0.322^{* *} \\
(0.143)\end{array}$ & $\begin{array}{c}-0.0579 * * * \\
(0.0159)\end{array}$ & $\begin{array}{c}-0.0574 * * * \\
(0.0155)\end{array}$ \\
\hline $\operatorname{Ln}(\operatorname{Exp})^{2}$ & & & & $\begin{array}{l}-0.0191 * * \\
(0.00843)\end{array}$ & $\begin{array}{l}0.000525 \\
(0.00137)\end{array}$ & $\begin{array}{l}0.000532 \\
(0.00135)\end{array}$ \\
\hline Hh size & $\begin{array}{c}0.000593 \\
(0.000583)\end{array}$ & $\begin{array}{l}0.00154 * * \\
(0.000749)\end{array}$ & $\begin{array}{c}0.000862 \\
(0.000770)\end{array}$ & $\begin{array}{c}0.00186 \\
(0.00127)\end{array}$ & $\begin{array}{l}-0.00321 \\
(0.00380)\end{array}$ & $\begin{array}{l}-0.00326 \\
(0.00372)\end{array}$ \\
\hline Proximity & $\begin{array}{l}-0.00941^{*} \\
(0.00563)\end{array}$ & $\begin{array}{l}-0.00560 \\
(0.00650)\end{array}$ & $\begin{array}{l}-0.00150 \\
(0.00695)\end{array}$ & $\begin{array}{c}-0.0116 \\
(0.00934)\end{array}$ & $\begin{array}{c}0.00371 \\
(0.00890)\end{array}$ & $\begin{array}{c}0.00406 \\
(0.00886)\end{array}$ \\
\hline Rural & $\begin{array}{l}-0.00420 \\
(0.00468)\end{array}$ & $\begin{array}{l}-0.00922 \\
(0.00901)\end{array}$ & $\begin{array}{l}-0.00599 \\
(0.00863)\end{array}$ & $\begin{array}{c}0.0323 * * \\
(0.0140)\end{array}$ & $\begin{array}{l}-0.00367 \\
(0.0101)\end{array}$ & $\begin{array}{l}-0.00123 \\
(0.00962)\end{array}$ \\
\hline Age & $\begin{array}{c}0.000603 \\
(0.000384)\end{array}$ & $\begin{array}{l}0.00129 * * \\
(0.000543)\end{array}$ & $\begin{array}{l}0.00139 * * \\
(0.000595)\end{array}$ & $\begin{array}{c}0.00163^{*} \\
(0.000862)\end{array}$ & $\begin{array}{l}0.00207 * * \\
(0.000843)\end{array}$ & $\begin{array}{l}0.00218^{* *} \\
(0.000862)\end{array}$ \\
\hline $\mathrm{Age}^{\wedge} 2$ & $\begin{array}{c}-0.000032 * * \\
(0.0000146)\end{array}$ & $\begin{array}{l}-0.0001 * * * \\
(0.0000229)\end{array}$ & $\begin{array}{c}-0.00009 * * * \\
(0.0000264)\end{array}$ & $\begin{array}{l}-0.0001 * * * \\
(0.0000412)\end{array}$ & $\begin{array}{c}-0.00014 * * * \\
(0.0000477)\end{array}$ & $\begin{array}{l}-0.00015 * * * * \\
(0.0000482)\end{array}$ \\
\hline Remittances & & & & & & $\begin{array}{l}-0.0138 \\
(0.0103)\end{array}$ \\
\hline Constant & $\begin{array}{c}0.0822 * * * \\
(0.0148)\end{array}$ & $\begin{array}{c}0.279 * * * \\
(0.0631)\end{array}$ & $\begin{array}{c}0.356 * * * \\
(0.0866)\end{array}$ & $\begin{array}{c}-1.156^{* *} \\
(0.539)\end{array}$ & $\begin{array}{c}0.541 * * * \\
(0.143)\end{array}$ & $\begin{array}{c}0.540 * * * \\
(0.141)\end{array}$ \\
\hline $\begin{array}{l}\text { N; } 1927 . \text { Tes } \\
\text { Sargan/Hans } \\
\text { Test of exclu } \\
\mathrm{F}=18.17, p- \\
\text { Kleibergen-F } \\
\text { Standard err }\end{array}$ & $\begin{array}{l}\text { lue }=0 ; \mathrm{F}=29.97 \\
\text { ip Wald rk LM } \\
\text { in parentheses }\end{array}$ & $\begin{array}{l}\text { or Kin, Ln Ex } \\
p \text {-value }=0 . \\
\text { tatistic } 7.004 \text {, } \\
<0.10, * * p\end{array}$ & $\begin{array}{l}\text { ty test (Wu-H } \\
\text { instruments) } \\
\text { diture and } \mathrm{Ho} \\
\text { value: } 0.03 \text {. }\end{array}$ & $\begin{array}{l}\text { sman } F \text { test): } \\
\text { value }=0 . \\
\text { hold size res }\end{array}$ & $\begin{array}{l}2.88 \mathrm{~F}(3,1913 \\
\text { ctively }): F=8 .\end{array}$ & $\begin{array}{l}- \text { value }=0 \\
p \text {-value }=0\end{array}$ \\
\hline
\end{tabular}


Table 6 Saving and Kinship Proxy

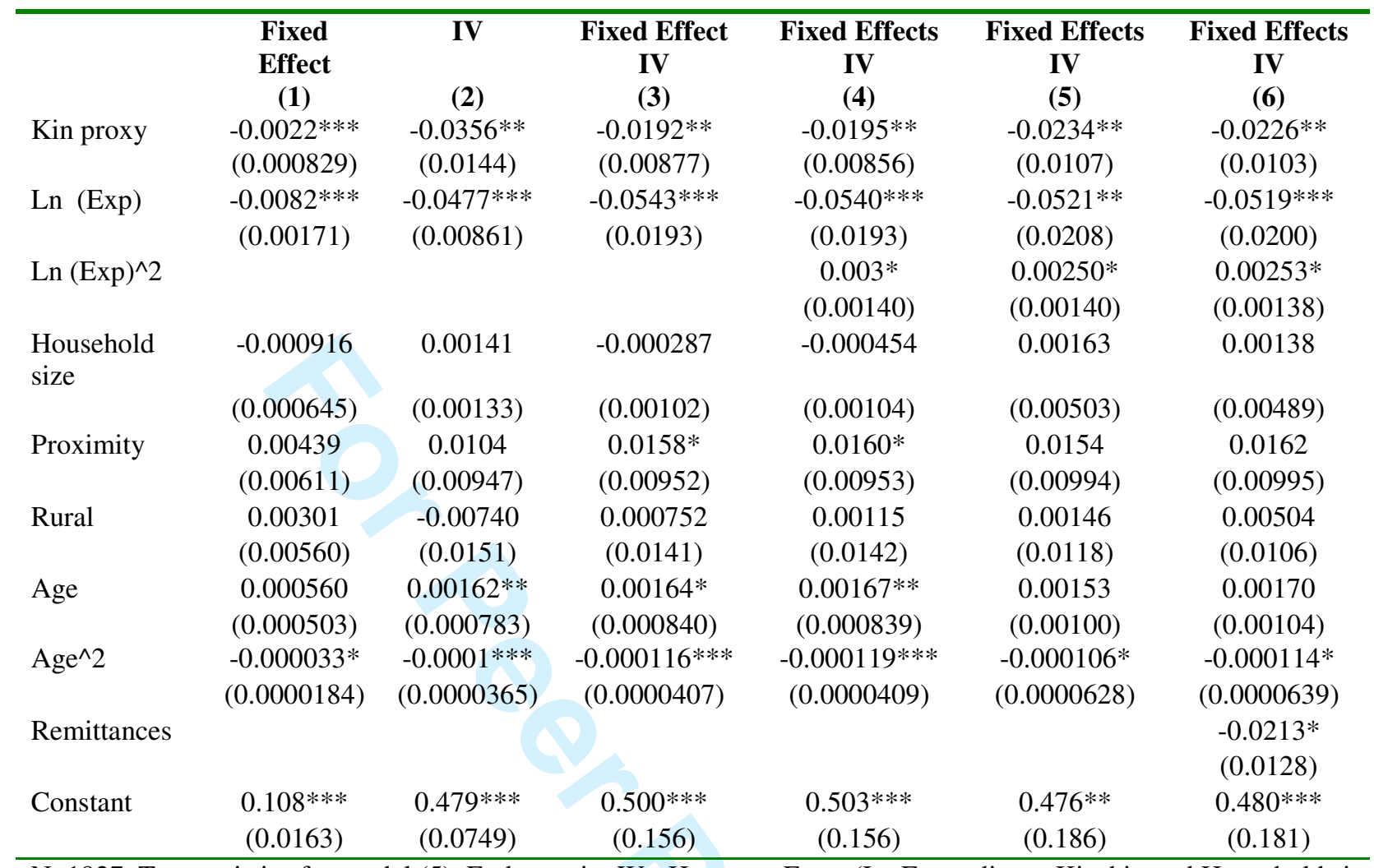

N: 1927. Test statistics for model (5). Endogeneity Wu-Hausman F test (Ln Expenditure, Kinship and Household size $\mathrm{F}(3,1913) p$-value $=0$. Sargan/Hansen (overidentification test of all instruments): $p$-value: 0.25 . Test of excluded in Kin, Ln Expenditure, Household size, respectively): $\mathrm{F}=8.03, p$ value: $0 ; \mathrm{F}=18.17, p$-value: $0 ; \mathrm{F}=29.97, p$-value $=0$. Paap Wald rk LM statistic 7.003 P-value: 0.0301. Standard errors in parentheses $p<0.10$, ** $p<0.05$, *** $p<0.01$ 
Table 7: The effect of kinship on income: four different income segments

\begin{tabular}{|c|c|c|c|c|}
\hline & Quintile $<30$ & Quintile $30-50$ & Quintile $50-70$ & Quintile $70-90$ \\
\hline Kin Network & $\begin{array}{c}-258.9 * * * \\
(43.19)\end{array}$ & $\begin{array}{c}-611.4 * * * \\
(51.75)\end{array}$ & $\begin{array}{c}-1106.2 * * * \\
(82.24)\end{array}$ & $\begin{array}{c}-2220.4 * * * \\
(294.7)\end{array}$ \\
\hline Household size & $\begin{array}{c}25.30 \\
(19.01)\end{array}$ & $\begin{array}{c}58.06 \\
(45.24)\end{array}$ & $\begin{array}{c}253.1 * * \\
(126.0)\end{array}$ & $\begin{array}{c}104.6 \\
(239.6)\end{array}$ \\
\hline Proximity & $\begin{array}{c}67.06 \\
(227.5)\end{array}$ & $\begin{array}{c}127.0 \\
(398.9)\end{array}$ & $\begin{array}{c}70.79 \\
(736.7)\end{array}$ & $\begin{array}{c}1870.3 \\
(1650.3)\end{array}$ \\
\hline Rural & $\begin{array}{c}-899.7 * * * \\
(281.5)\end{array}$ & $\begin{array}{c}-1566.5^{* * *} \\
(493.1)\end{array}$ & $\begin{array}{c}-4046.3 * * * \\
(1122.4)\end{array}$ & $\begin{array}{c}-10473.4 * * * \\
(1906.2)\end{array}$ \\
\hline Age & $\begin{array}{c}40.34 * * * \\
(13.20)\end{array}$ & $\begin{array}{l}74.02 * \\
(41.30)\end{array}$ & $\begin{array}{c}90.78 \\
(85.29)\end{array}$ & $\begin{array}{c}321.5 \\
(269.2)\end{array}$ \\
\hline Constant & $\begin{array}{c}3186.9 * * * \\
(295.6)\end{array}$ & $\begin{array}{c}6337.8 * * * \\
(634.8)\end{array}$ & $\begin{array}{c}12033.4 * * * \\
(1153.9)\end{array}$ & $\begin{array}{c}31640.6 * * * \\
(3648.0)\end{array}$ \\
\hline
\end{tabular}


Appendix

Table First stage regressions from models reported in columns (5)

Equation

$\begin{array}{ll} & \text { Proximity } \\ & \text { Rural } \\ \text { Assets } & \text { Age } \\ & \text { Age^2 } \\ & \text { Avg HH size } \\ & \text { Total Income } \\ & \text { Tot Income }{ }^{\wedge} 2 \\ \text { Avg Kin }\end{array}$

Home

$\mathrm{Age}$

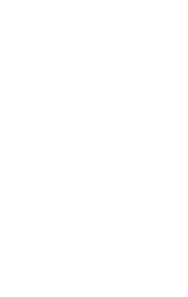

\section{Furniture $\quad \mathrm{Age}^{\wedge} 2$}

Avg HH size

Total Income

Tot Income^2

Avg Kin

\section{Proximity}

Rural

Cloth

Age

$\mathrm{Age}^{\wedge} 2$

Avg HH size

Total Income

Tot Income^2

Avg Kin

Proximity

Rural

Age

Jewels

$\mathrm{Age}^{\wedge} 2$

Avg HH size

Total Income

Tot Income ${ }^{\wedge} 2$

Avg Kin

Kin

Co

$$
\begin{array}{r}
\text { Coe } \\
0.02 \\
0.29 \\
0.01 \\
-0.00 \\
0.24 \\
-0.000 \\
-0.000 \\
0.01 \\
-0.06 \\
0.58 \\
-0.05 \\
0 .
\end{array}
$$

Coeffs.

0.022

0.292

0.013

$-0.001$

0.246

$-0.000005$

$-0.000009$

0.010

\section{$-0.063$}

0.585

$-0.053$

0.0001

0.196

$-0.000005$

$-0.000001$

0.008

$-0.063$

0.585

$-0.053$

0.0001

0.196

$-0.000005$

$-0.000001$

0.008

0.016

0.662

$-0.029$

0.001

0.200

$-0.000004$

$-0.000007$

0.010

0.022

0.292

0.013

$-0.001$

0.246

$-0.000005$

$-0.000009$

0.010
0.121

0.126

0.009

0.001

0.043

0.000002

0.000005

0.002

\subsection{9}

0.202

0.015

0.001

0.050

0.000002

0.000007

0.002

0.179

0.202

0.015

0.001

0.050

0.000002

0.000007

0.002

\subsection{4}

0.263

0.020

0.002

0.071

0.000002

0.000009

0.003

$0.121 \quad 0.140$

0.126

0.009

0.001

0.043

$\begin{array}{ll}0.000002 & -0.000002\end{array}$

0.000005

0.002
$-0.000046$
$-0.671$

0.028

$-0.002$

0.057

\section{Ln Exp}

Std Errs

$-0.671$

0.028

$-0.002$

0.057

.000002

$-0.006$

\subsection{1}

0.354

0.028

-0.001
-0.127

$-0.000002$

$-0.000030$

$-0.008$

0.161

0.354

$-0.001$

$-0.127$

$-0.000002$

$-0.000030$

0.202

0.321

$-0.001$

$-0.086$

$-0.000002$

$-0.000041$

$-0.005$

$-0.006$

\subsection{8}

0.122

0.009

0.001

0.042

0.000002

0.000005

0.002

\subsection{4}

0.095

0.007

0.001

0.023

0.000001

0.000003

0.001

0.084

0.095

0.007

0.001

0.023

0.000001

0.000003

0.001

0.102

0.115

0.009

0.001

0.031

0.000001

0.00000

0.001

0.118

0.122

0.009

0.001

0.042

0.000002

0.000005

0.002

\section{HH size}

Coeffs. Std Errs

0.117

0.920

0.063

$-0.007$

0.893

$-0.000001$

0.000008

$-0.003$

0.070

0.470

0.156

$-0.012$

0.913

$-0.000001$

-0.000029
-0.0001

0.000

0.070

0.470

0.156

$-0.012$ 